\title{
Seed and seedling characteristics of hybrid chestnuts (Castanea spp.) derived from a backcross blight-resistance breeding program
}

\author{
Martin Cipollini ${ }^{1}$ (D) Nicholas Wessel ${ }^{1} \cdot$ John Patten Moss $^{1} \cdot$ Natalie Bailey $^{1}$
}

Received: 19 February 2019 / Accepted: 27 August 2019 / Published online: 16 September 2019

(c) The Author(s) 2019

\begin{abstract}
American chestnut (Castanea dentata) was a foundation species in the eastern United States until chestnut blight (Cryphonectria parasitica) infestation resulted in range-wide catastrophic reduction. Since 1983, The American Chestnut Foundation (TACF) has engaged in a breeding program aimed at restoring $C$. dentata to the wild. The primary goal has been to introduce blight resistance from Castanea mollissima while recovering a $C$. dentata phenotype via successive backcrosses. To diversify the genetic base, state chapters of TACF have been producing $\mathrm{BC}_{3}$ and $\mathrm{BC}_{4}$ (third and fourth backcross) lines using $C$. dentata from across its native range. This study focuses on morphology and chemistry of seeds, and morphology and early growth of seedlings derived from $\mathrm{BC}_{3}$ and $\mathrm{BC}_{4}$ trees selected for blight resistance in state chapters. Our primary comparisons were among backcross, pure $C$. mollissima, and pure $C$. dentata lines. Seed traits included a suite of morphological characters known to differ between $C$. dentata and $C$. mollissima, as well as dry matter, total carbohydrate, sugar, protein, lipid, and phenolic content. Seedling traits included variables such as stem basal diameter and height, leaf variables such as number and area, and relative growth in key parameters such as stem volume. C. mollissima lines tended to differ significantly from $C$. dentata and backcross lines in most parameters, while $C$. dentata and backcross types tended to overlap broadly in traits. These results suggest that seed and seedling characteristics of backcross hybrids studied here are likely to be sufficiently similar to $C$. dentata for use in restoration programs.
\end{abstract}

Keywords Castanea dentata $\cdot$ Castanea mollissima $\cdot$ Species restoration $\cdot$ Backcross breeding $\cdot$ Disease resistance $\cdot$ Genetics

Electronic supplementary material The online version of this article (https://doi.org/10.1007/s 1105 6-019-09744-7) contains supplementary material, which is available to authorized users.

Martin Cipollini

mcipollini@berry.edu

1 Department of Biology, Berry College, Mount Berry, GA 30149, USA 


\section{Introduction}

As of the late nineteenth century, American chestnut, Castanea dentata (Marsh.) Borkh. (Fagaceae; hereafter AM chestnut) flourished across eastern North America and provided rural residents with timber and a cash crop, at the same time being a valuable food resource for wild animals due to a consistent and abundant production of nuts (Anagnostakis 1987; Wang et al. 2013). Chestnut blight, caused by Cryphonectria parasitica (Murrill) Barr (Cryphonectriaceae), was introduced to AM chestnuts in or before 1905, apparently having been imported on Japanese/Korean chestnut (C. crenata Siebold \& Zucc.) and/or Chinese chestnut ( $C$. mollissima Blume [hereafter $\mathrm{CH}$ chestnut]; Milgroom and Cortesi 2004). After entering the bark via air-borne spores, cankers spread quickly in susceptible trees, and eventually girdle and kill the stem. The portion of the stem below the canker often remains alive and basal sprouting may occur following infection (Griffin et al. 1983). Because of the lack of resistance in AM chestnut, by 1950 the disease had spread throughout its native range, top-killing approximately four billion trees (Jacobs et al. 2013). Currently, $431 \pm 30.2$ million AM chestnuts remain, but the vast majority $(360 \pm 22$ million) are small $(<2.5 \mathrm{~cm}$ in diameter; Dalgleish et al. 2015). These sprouts, along with far lower numbers of large long-term surviving AM chestnut trees, provide germplasm resources for projects designed to restore AM chestnut as a functional component of U.S. forests.

Many strategies to develop resistance to the chestnut blight have been advanced, including biocontrol using hypovirulent strains (Milgroom and Cortesi 2004), cross-breeding surviving AM chestnuts (Griffin et al. 1983), genetic modification of AM chestnut (Zhang et al. 2013; Steiner et al. 2016), and hybridization with Asian chestnuts (Hebard 2005; Steiner et al. 2016). The American Chestnut Foundation (TACF) has focused since 1983 on a backcross breeding approach aimed at producing blight-resistant hybrids with phenotypic features of AM chestnut (Hebard 2012). In recent years, state chapters of TACF have also established backcross programs with the intent of generating regionally adapted backcross hybrids for restoration in their own regions (Fitzsimmons et al. 2012).

In the TACF backcross program, blight resistance genes are introduced to AM chestnut via crosses with $\mathrm{CH}$ chestnut (Burnham et al. 1986). Starting with these $\mathrm{F}_{1}$ hybrids, AM chestnut traits are recovered through a series of backcrosses with AM chestnuts. Backcross trees are selected to advance to the next generation based upon assessments of blightresistance and morphology. In third generation backcross $\left(\mathrm{BC}_{3}\right)$ trees, the $\mathrm{AM}$ chestnut complement of the genome should on average be 94\% (15/16th AM chestnut and 1/16th $\mathrm{CH}$ chestnut) and fourth backcross $\left(\mathrm{BC}_{4}\right)$ trees $97 \%$ (31/32th $\mathrm{AM}$ chestnut and 1/32th $\mathrm{CH}$ chestnut). The theoretical model (based upon two or three independently segregating, incompletely dominant genes) that formed the basis for the TACF backcross program predicted that backcross trees should harbor intermediate levels of blight resistance (Burnham et al. 1986). Theoretically, full resistance is to be recovered by intercrossing $\mathrm{BC}_{3}$ (or $\left.\mathrm{BC}_{4}\right)$ trees to produce $\mathrm{BC}_{3} \mathrm{~F}_{2}\left(\mathrm{BC}_{4} \mathrm{~F}_{2}\right)$ trees, a small percentage of which may be genetically fixed for blight resistance. Selected $\mathrm{BC}_{3} \mathrm{~F}_{2}\left(\mathrm{BC}_{4} \mathrm{~F}_{2}\right)$ trees are inter-crossed to produce $\mathrm{BC}_{3} \mathrm{~F}_{3}\left(\mathrm{BC}_{4} \mathrm{~F}_{3}\right)$ offspring for restoration to natural sites. The theoretical model underpinning this approach is being assessed via developing molecular and classical genetic analyses (Georgi et al. 2015; Westbrook 2016; Westbrook et al. 2019a). The final intercrossing steps (beyond $\mathrm{BC}_{3}$ or $\mathrm{BC}_{4}$ ) are not intended to further alter the percentage of $\mathrm{AM}$ chestnut genes but merely to provide an opportunity for sets of blight-resistance genes to become homozygous. A parallel breeding program has been initiated in the southeast U.S. directed towards selection in C. dentata/C.mollissima hybrids for resistance to root rot caused by 
Phytophthora cinnamomi Rands (Jeffers et al. 2012). Recent data from the TACF backcross program suggest that $\mathrm{BC}_{3}$ trees may not achieve the high level of blight resistance originally hypothesized (Westbrook et al 2019a). Nevertheless, the $\mathrm{BC}_{3}$ generation remains a critical component of early restoration work involving blight resistance (Clark et al. 2019). The $\mathrm{BC}_{3} / \mathrm{BC}_{4}$ generations also represent important sources of $P$. cinnamomi resistance for the TACF breeding program (Westbrook et al. 2019b, c).

It is important to test the hypothesis that disease resistance and AM chestnut morphological and physiological traits can be found in backcross trees, particularly in trees emanating from state chapter programs that rely principally upon citizen scientists. For restoration, phenotype traits of backcross trees should exhibit the same range of variation as wild-type $\mathrm{AM}$ chestnuts. In this study, we assess seed and young seedling characteristics of nuts from $\mathrm{BC}_{3}$ and $\mathrm{BC}_{4}$ trees originating in state TACF chapters-trees that have been selected for blight resistance. Very little is known about the seed chemistry of AM chestnut and only a little more for the relatively better-studied European chestnut (C. sativa Mill.) and Asian species. One common finding is that the sugar profile of chestnuts tends to be dominated by sucrose, with glucose and fructose at very low levels (cf., Senter et al. 1994). It has commonly been reported that AM chestnuts are "sweeter" in taste than Asian and European species (Rosengarten 2004), although Senter et al. (1994) found only marginally higher sugars in AM chestnut in comparison with $\mathrm{CH}$ and European chestnuts. AM and $\mathrm{CH}$ chestnuts can be distinguished by a variety of nut morphologic traits including mass and dimensions (higher in $\mathrm{CH}$ chestnut), and relative length of the arms of the "starfish" shaped vascular scar within the hilum, relative length of the stigma and style, and surface trichome density (all higher in AM; The American Chestnut Foundation 2018). Regarding seedlings, some field studies using $\mathrm{BC}_{3}$ generation trees have demonstrated relatively minor differences in comparison with AM chestnuts (Clark et al. 2012; Knapp et al. 2014; Clark et al. 2016; Pinchot et al. 2017; see Skousen et al. 2018 for an exception). Backcross trees used in these studies were open-pollinated offspring of parents that had not been selected for blight resistance (early products of unculled $\mathrm{BC}_{3} \mathrm{~F}_{2}$ orchards). Linkage between blightresistant genes and genes affecting seedling morphology and physiology could produce results that are different for backcross trees selected for blight resistance. In this study, we focus on nut morphological traits, embryo nutrient and phenolic content, and early growth characteristics of nursery-grown seedlings (the time-frame when maternal effects related to seed reserves should most strongly affect offspring morphology and growth). We predicted that: (1) AM and $\mathrm{CH}$ chestnuts would be routinely distinguishable in nut and seedling morphology, embryo chemistry, and early seedling growth, and (2) Blight-resistant $\mathrm{BC}_{3}$ and $\mathrm{BC}_{4}$ trees would produce nuts whose morphology, seed chemistry, and seedling morphology and growth is indistinguishable from AM chestnut.

\section{Materials and methods}

\section{Study site and genetic material}

TACF backcross breeding orchards were established by TACF state chapters at a variety of locations (Supplement 1). Trees planted at these sites were $\mathrm{BC}_{3}$ or $\mathrm{BC}_{4}$ trees, bred using $\mathrm{BC}_{2}$ or $\mathrm{BC}_{3}$ Graves/Mahogany-source trees at TACF's Meadowview, VA research farm as either male or female parents. Breeding was done via hand-pollination using pollen collected from wild AM trees (backcross trees as female parents) or pollen collected from 
backcross trees (wild AM trees as female parents). AM chestnuts used in the breeding program came from wild trees located in the state corresponding to the orchard location (Georgia, Kentucky, Pennsylvania, or Tennessee), and species identification was confirmed by consensus of TACF experts.

Blight resistance testing of $\mathrm{BC}_{3}$ and $\mathrm{BC}_{4}$ trees was conducted using similar methods at all orchard sites. Description of the inoculation process and evaluation of cankers can be found in Cipollini et al. (2017). Trees with favorable blight resistance were then assessed for $\mathrm{AM}$ chestnut phenotype based upon a battery of leaf, stem and bud traits. Selected $\mathrm{BC}_{3} / \mathrm{BC}_{4}$ trees were maintained within each backcross orchard. Non-selected trees were culled or emasculated, and the selected survivors were permitted to open-pollinate to produce $\mathrm{BC}_{3} \mathrm{~F}_{2}$ or $\mathrm{BC}_{4} \mathrm{~F}_{2}$ offspring. These were the focal nuts evaluated in this study; $23 \mathrm{BC}_{3}$ (includes one $\mathrm{BC}_{3} \mathrm{~F}_{3}$ line) and $9 \mathrm{BC}_{4}$ lines (Supplement 1). To help control for genetic lineage, no more than two trees from the same parental cross were included in any chemical or physical comparison. We also included seedlots from wild-type AM chestnut $(\mathrm{N}=16)$ and $\mathrm{CH}$ chestnuts $(\mathrm{N}=8)$.

\section{Seed harvest and physical analyses}

For physical and chemical analysis, seeds were harvested from trees in fall of 2015 and 2017 (Supplement 1). In 2015, nuts ( $\mathrm{N}=10-25$ per line; $\mathrm{N}=3 \mathrm{AM}, 4 \mathrm{BC}_{4}, 4 \mathrm{BC}_{3}$, and 4 $\mathrm{CH})$ were shucked from husks and surface-sanitized with Sanidate $5.0(9 \mathrm{~g} / \mathrm{L})$ for $5 \mathrm{~min}$. Nuts were air-dried briefly, packed in plastic zip-lock bags, and held for $\sim 30$ days at $4{ }^{\circ} \mathrm{C}$ until further processing (this period was selected to optimize after-ripening that affects sugar profiles of chestnut seeds; Chenlo et al. 2010). Each nut was weighed to the nearest $0.001 \mathrm{~g}$, and length (L), widest width (W), and narrowest depth (D) measured to nearest $0.01 \mathrm{~mm}$ (see Supplement 2 for a key to all traits assessed in this paper). Seed volume $(\mathrm{SVOL})$ was calculated from the average radius: $\mathrm{SVOL}=(4 / 3) * 3.1416 *((\mathrm{~L} / 2+\mathrm{W} / 2+\mathrm{D}$ /2)/3). Subsamples of 5-10 seeds from selected lines were peeled to remove nut and seed coats, chopped into small particles, weighed to nearest $0.001 \mathrm{~g}$, placed into drying oven at $60{ }^{\circ} \mathrm{C}$, dried to constant mass, and reweighed. Dry matter content (g/g wet mass) was calculated as mass $(\mathrm{g})$ of dried sample/mass ( $\mathrm{g}$ ) of wet sample. Duplicate sub-samples were prepared for chemical analysis by freezing chopped embryo particles to $-80{ }^{\circ} \mathrm{C}$ and lyophilizing. Dried samples were milled to pass a 40 mil mesh screen and stored at $-20{ }^{\circ} \mathrm{C}$. Residual water in lyophilized samples was estimated by loss of mass upon drying of $\sim 0.2 \mathrm{~g}$ subsamples at $60{ }^{\circ} \mathrm{C}$ for $24 \mathrm{~h}$, and was taken into account when estimating chemical content.

\section{Nut morphology}

In the fall of 2017 , individual nuts from $11 \mathrm{AM}, 3 \mathrm{BC}_{4}, 15 \mathrm{BC}_{3}$, and $7 \mathrm{CH}$ lines $(\mathrm{N} \sim 25$ per line) were measured to the nearest $0.01 \mathrm{~mm}$ as follows:

1. L, W, D, and SVOL of each nut, as for 2015 samples.

2. Width (HW) and height $(\mathrm{HH})$ of the hilum scar.

3. Length of the longest "arm" of the starfish shaped vascular scar within the hilum (AL).

4. Length of the stigma plus style (SL).

From the above values, we calculated the following parameters: 
1. Hilum area (HA): $\mathrm{HA}=3.1416 *(\mathrm{HW} / 2) *(\mathrm{HH} / 2)$.

2. Hilum area/surface area ratio (HASA): HASA $=$ HA/SA.

3. Hilum width/seed width ratio (HWSW): HWSW $=\mathrm{HW} / \mathrm{SW}$.

4. Arm length/hilum width ratio (ALHW): ALHW $=$ AL/HW

5. Stigma/style length to seed length ratio (SLL): SLL $=$ SL/L.

6. Surface area: While the surface area of a general ellipsoid cannot be expressed exactly by a mathematical function, we used the following approximate formula to calculate nut surface area (Michon 2018): $\mathrm{SA} \sim 4 * 3 / 1415 *\left[\left(\mathrm{~L}^{\mathrm{p}} * \mathrm{~W}^{\mathrm{p}}+\mathrm{L}^{\mathrm{p}} * \mathrm{D}^{\mathrm{p}}+\mathrm{W}^{\mathrm{p} *} \mathrm{D}^{\mathrm{p}}\right) / 3\right]^{\{1 \mathrm{p}\}}$, where $\mathrm{p}=1.6075$.

Using a hand lens, hairiness (HRS) of the upper half of each nut was visually estimated on a scale of $0 \%$ (no hairs visible) to $100 \%$ (no nut surface visible).

Nut samples from $2017\left(\mathrm{~N}=9 \mathrm{AM}, 8 \mathrm{BC}_{3}\right.$, and $\left.5 \mathrm{CH}\right)$ were prepared for chemical analysis using the same methods for 2015 samples.

\section{Embryo nutrient analyses}

Using dried, milled samples from 2015 and 2017, we measured the following constituents:

1. Total nonstructural carbohydrates (TNC) and total sugars using the anthrone method (Yemm and Willis 1954; Spiro 1966) following amylase digestion of $\sim 0.01 \mathrm{~g}$ samples for TNC (Smith 1981) and 80\% methanol extraction of $\sim 0.05 \mathrm{~g}$ samples for total sugars ( $\mathrm{Li}$ et al. 1985). Results were expressed as \% dry mass soluble starch equivalents for TNC (starch standards) and \% dry mass sucrose equivalents for sugars (sucrose standards).

2. Total lipids using gravimetric analysis of $\sim 0.2 \mathrm{~g}$ samples extracted for $16 \mathrm{~h}$ with petroleum ether using a Soxhlet apparatus (AOAC International 2012). Results were expressed as \% dry mass crude fat content.

3. Total proteins using the Bradford assay (Jones et al. 1989) using $0.1 \mathrm{~N} \mathrm{NaOH}$ extraction of $\sim 0.02 \mathrm{~g}$ samples. Results were expressed as \% dry mass bovine serum albumin equivalents (BSA standards).

4. Total phenolics using the Prussian Blue assay (Budini et al. 1980) following acidified methanol extraction of $\sim 0.05 \mathrm{~g}$ samples. Results were expressed as $\mathrm{mg} / \mathrm{g}$ catecholic acid equivalents (catecholic acid standards).

5. Sucrose and glucose (2015 samples only) using the Sigma-Aldrich SCA20 sucrose assay (Sigma-Aldrich.com, St. Louis, MO) following water extraction of $\sim 0.3 \mathrm{~g}$ samples. This assay allows for the simultaneous estimation of free glucose as well as glucose released enzymatically from sucrose. Previous analysis of sugars in chestnuts suggest that sucrose dominates the sugar profile, with glucose and fructose at much lower levels and with other sugars in trace amounts; e.g., Senter et al. 1994; De Vasconcelos et al. 2010; Hernández Suárez et al. 2012).

For each of the above assays, duplicate samples were run and spectrophotometric measurements were made using a Spectronic 20 D + (Thermo Scientific, Waltham, MA) set to the appropriate wavelength for each analysis. Analyses were repeated one additional time if the first two replicates differed by $>5 \%$. 


\section{Seedling measurements}

Replicate seedlots from fall $2015\left(\mathrm{~N}=3 \mathrm{AM}, 9 \mathrm{BC}_{3}, 3 \mathrm{BC}_{4}\right.$, and $\left.4 \mathrm{CH}\right)$ were stored in moist, sterile peat moss at $4{ }^{\circ} \mathrm{C}$ in plastic bags. Seeds were planted on 4 February 2016 in D40 pots (Steuwe and Sons, Inc., Tangent, OR) in media comprised of 1:1 coarse vermiculite:Pro Mix BX (Premier Horticulture, Quakertown, PA). Seedlings were moved outdoors on 14 March 2016 and maintained under 50\% neutral shade cloth under ambient conditions.

On 4 April 2016, 10 seedlings randomly selected from each line were measured for leaf number $(\mathrm{LN})$, stem height $(\mathrm{HT} ; \mathrm{cm})$, and basal diameter $(\mathrm{BD} ; \mathrm{mm})$ of the main stem (measured at the soil surface). From these measurements, we calculated basal area $\left(\mathrm{BA}=\pi *(\mathrm{BD} / 2)^{2}\right)$, stem height-to-basal area ratio $(\mathrm{HTBA}=\mathrm{HT} / \mathrm{BA})$, and stem volume estimated as a cone $(\mathrm{VOL}=\mathrm{BA} * \mathrm{HT}) / 3)$. The largest leaf on each seedling was measured for length $(\mathrm{LL} ; \mathrm{cm})$ and width $(\mathrm{LW} ; \mathrm{cm})$ at the midpoint on the leaf axis. These measurements were used to calculate leaf area as an ellipse $\left(\mathrm{LA}=\pi *((\mathrm{LL} / 2) *(\mathrm{LW} / 2))^{2}\right.$ and leaf length-to-width ratio (LLLW $=\mathrm{LL} / \mathrm{LW})$.

One week later (11 April 2016), measurements were taken on the same seedlings. For each parameter $\mathrm{P}$, relative growth rate $(\mathrm{RGR})$ per time unit was calculated as $(\ln \mathrm{P} 2-\ln \mathrm{P} 1) /$ $(\mathrm{t} 2-\mathrm{t} 1)$. For logistical reasons (seedlings needed to be transplanted to a remote field site on 12 April 2016), there was a relatively short interval (1 week) between successive measurements. We therefore repeated the growth experiment with additional lines collected in fall 2016 ( $3 \mathrm{AM}, 3 \mathrm{BC}_{4}$, and $6 \mathrm{BC}_{3}$ lines; $\mathrm{N}=20$ per line), planted in late January 2017, and moved outdoors in mid-March 2017. These seedlings was measured at two periods (17 April and 23 May 2017; 36 day growth period) and morphological/growth parameters calculated as in 2016.

\section{Statistics}

Means for variables were compared among genetic types using a series of one-way ANOVAs (hereafter ANOVA; Statistix 10; Analytical Software 2013). Significant ANOVAs were followed by Tukey's HSD All Pairwise Comparisons $(\alpha=0.05$; hereafter Tukey's tests) comparing genetic types. Non-parametric Kruskal-Wallis (hereafter $\mathrm{K}-\mathrm{W}$ ) tests were used for analysis of embryo chemical data. For these analyses, data were available on only two or three replicate analyses per line, and dependent variables could not be transformed to fit requirements of equal variance and normality for parametric tests. Significant K-W results were followed by Dunn's All Pairwise Comparisons $(\alpha=0.05$; hereafter Dunn's tests) comparing genetic types. We used genetic type $(\mathrm{CH}, \mathrm{AM}$, etc.) as the independent variable and conducted ANOVA or $\mathrm{K}-\mathrm{W}$ tests using the mean value for each genetic line. For lines that had both seed and seedling traits measured, we also regressed mean SVOL on average seed size (either dry mass or VOL) to assess this relationship.

Because dependent variables tended to be strongly correlated, we also used Principle Components Analysis (PCA) to generate a smaller number of uncorrelated variables (PC variables) for parametric analysis using ANOVA. We conducted ANOVA/ Tukey's tests comparing PC scores among genetic lines or types for the first two principal components from each experiment. As with the original variables, we used mean values for each genetic line and genetic type as the independent variable. Nested ANOVA (genetic lines nested within genetic type) might have been appropriate for the 
basic data structure. However, differences in the number of genetic lines within genetic type (unbalanced design) renders calculation and interpretation of $\mathrm{F}$ values from nested ANOVA problematic (McDonald 2014). In our analyses, ANOVA using genetic lines and genetic type gave qualitatively similar results, so for simplicity we present the latter.

\section{Results}

\section{Nut morphology, 2015 samples}

In 2015, nuts differed significantly among genetic types in L, W, D, wet and dry mass and SVOL. ANOVA results for each of these highly correlated variables were qualitatively similar (all $\mathrm{F}_{3,11}$ values $>19$ using log-transformed data; all $P$ values $<0.001$ ), so we show only results for SVOL (Fig. 1). Average SVOL was about three times higher for $\mathrm{CH}$ lines in comparison with $\mathrm{AM}$ and backcross lines. As expected, AM and backcross types tended to have much smaller dimensions, masses and volumes in comparison with $\mathrm{CH}$ types.

The first axis of the PCA using morphological variables explained $>87 \%$ of the overall variation (see Supplement 3 for detailed results for these and all other PCA analyses), rendering consideration of other PCA axes needless. This axis (PC1) was negatively associated with size and mass variables (most strongly with masses and SVOL; dimensional variables less so). ANOVA using PC1 scores (Fig. 1) showed two groups ( $\mathrm{AM}=\mathrm{BC}_{4}=\mathrm{BC}_{3}$, and $\mathrm{BC}_{4}=\mathrm{BC}_{3}=\mathrm{CH}$ ). While this analysis did not segregate $\mathrm{CH}$ and backcross types statistically, the magnitude of the difference between backcross and $\mathrm{CH}$ types was pronounced in comparison with the magnitude of the difference between backcross and AM types.

\section{Embryo chemistry, 2015 and 2017 samples}

Embryo dry matter, sucrose, and glucose from 2015 samples averaged $0.55 \mathrm{~g} / \mathrm{g}, 5.6 \%$, and $0.4 \%$ respectively. While sucrose and glucose did not differ among types according to Dunn's tests, dry matter differed significantly between AM and $\mathrm{CH}$ types, both of which overlapped with backcross types (Table 1).

Embryo chemistry from combined 2015 and 2017 samples varied among genetic types, particularly for lipids, which ranged from 11 to $15 \%$ for $\mathrm{AM}$ and backcross types to only $2.6 \%$ for $\mathrm{CH}$ types (Table 2 ). $\mathrm{AM}, \mathrm{BC}_{4}$, and $\mathrm{BC}_{3}$ types did not differ significantly in any chemical constituent. Protein content showed some suggestion of an intermediate value for backcross lines in that two statistical groups were recognized $\left(\mathrm{CH}=\mathrm{BC}_{3}=\mathrm{BC}_{4}\right.$, and $\left.\mathrm{BC}_{3}=\mathrm{BC}_{4}=\mathrm{AM}\right)$. Most likely a result of a trade-off with lipid content, $\mathrm{CH}$ lines tended to be higher in TNC, starch and sugars, although the only statistically significant difference was that $\mathrm{TNC}$ was greater for $\mathrm{CH}$ than for $\mathrm{BC}_{3}$ types.

The first two axes of the PCA using embryo chemical variables explained $\sim 65 \%$ of the overall variation ( 39\% for PC1 and 26\% for PC2). PC1 scores differed significantly among genetic types based upon ANOVA (Fig. 2), although PC2 scores did not. AM, BC 4 , and $\mathrm{BC}_{3}$ types formed a homogenous group on $\mathrm{PC} 1$ (high values) that differed significantly from $\mathrm{CH}$ types. $\mathrm{PC} 1$ scores related positively to lipid and protein content, and negatively to sugar and starch content. 

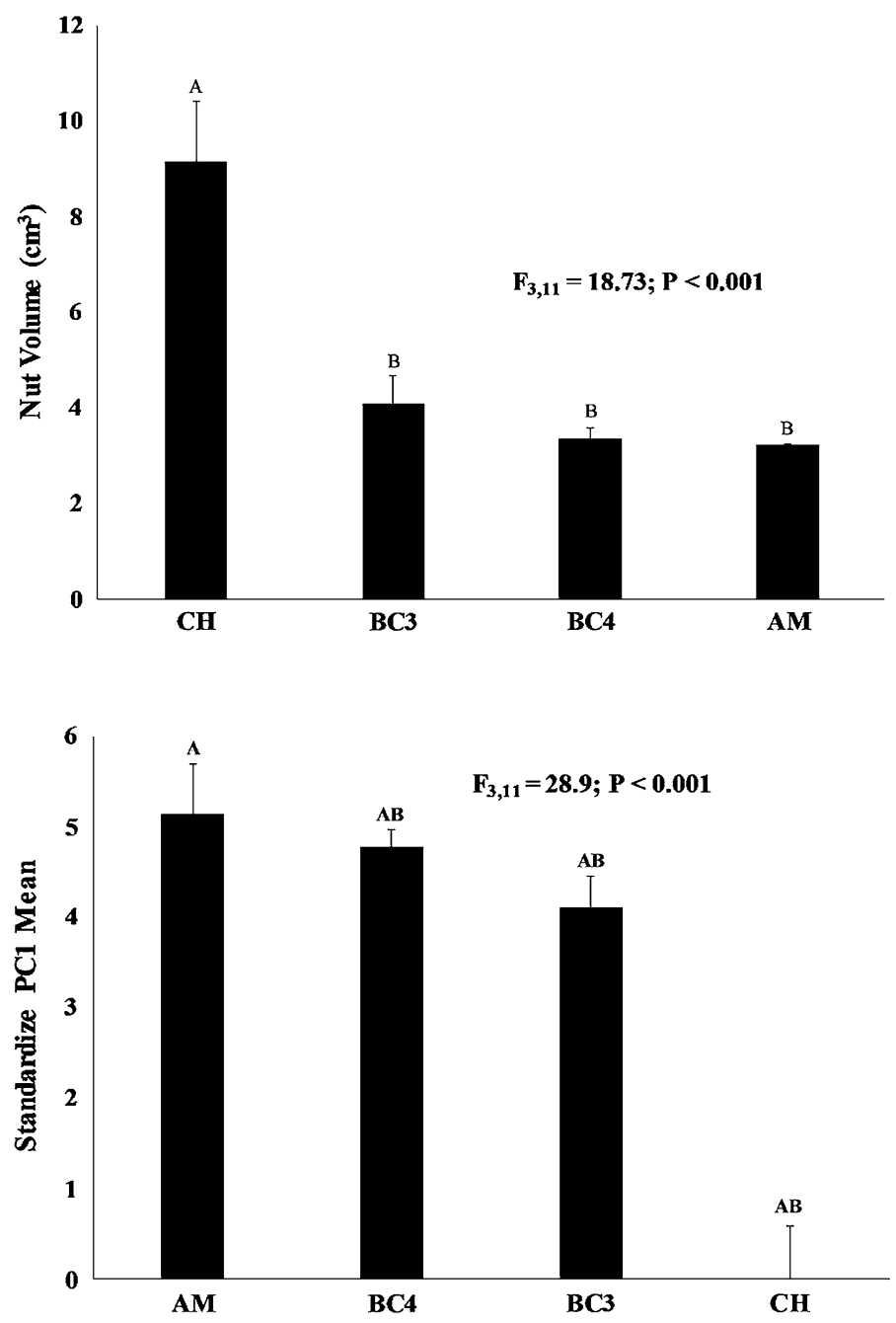

Fig. 1 Mean ( \pm S.E.) nut volume (SVOL; upper figure) and PC1 scores (standardized by subtracting the minimum; lower figure) for nut morphological data collected from 2015 samples $\left(\mathrm{N}=4 \mathrm{CH}, 4 \mathrm{BC}_{3}, 4 \mathrm{BC}_{4}\right.$, and 3 AM lines). Identical letters denote genetic types that did not differ statistically $(P>0.05)$ based upon Tukey's tests following one way ANOVA

\section{Nut morphology 2017 samples}

Similar to results from 2015 samples, nuts from $\mathrm{CH}$ types tended to have higher overall dimensions in comparison with $\mathrm{AM}, \mathrm{BC}_{4}$, and $\mathrm{BC}_{3}$ types (Table 3). Significant differences were detected among genetic types for all morphological variables except HASA, AL, and ALHW. For variables that differed significantly among genetic types, in no case did $\mathrm{BC}_{3}$ or $\mathrm{BC}_{4}$ types differ from $\mathrm{AM}$ types. Probably due low sample sizes for the $\mathrm{BC}_{4}$ type $(\mathrm{N}=3$ lines), $\mathrm{BC}_{4}$ lines could not be distinguished from $\mathrm{CH}$ types for several variables (e.g., $\mathrm{L}$, $\mathrm{HW}, \mathrm{HH}$, and HWSW). Again, focusing on variables that differed significantly among 
Table 1 Embryo dry matter, sucrose, and glucose content and $\mathrm{K}-\mathrm{W}$ results for samples collected in 2015 $\left(\mathrm{N}=4 \mathrm{CH}, 4 \mathrm{BC}_{3}, 4 \mathrm{BC}_{4}\right.$, and $3 \mathrm{AM}$ lines)

\begin{tabular}{|c|c|c|c|c|c|c|c|c|c|}
\hline \multicolumn{4}{|c|}{ Dry matter ${ }^{\mathrm{a}}(\mathrm{g} / \mathrm{g})$} & \multicolumn{3}{|c|}{ Sucrose $^{\mathrm{b}}$ (\% dry mass) } & \multicolumn{3}{|c|}{ Glucose $^{\mathrm{b}}$ (\% dry mass) } \\
\hline \multirow{2}{*}{$\frac{\text { Type }}{\mathrm{CH}}$} & \multirow{2}{*}{$\begin{array}{c}\text { Mean } \\
0.531\end{array}$} & \multicolumn{2}{|l|}{ SD } & \multirow{2}{*}{$\begin{array}{c}\text { Mean } \\
5.60\end{array}$} & \multicolumn{2}{|l|}{ SD } & \multirow{2}{*}{$\begin{array}{l}\text { Mean } \\
0.19\end{array}$} & \multicolumn{2}{|l|}{ SD } \\
\hline & & 0.014 & $\mathrm{~A}$ & & 1.60 & A & & 0.33 & A \\
\hline $\mathrm{BC}_{3}$ & 0.553 & 0.011 & $\mathrm{AB}$ & 5.90 & 1.20 & A & 0.36 & 0.35 & A \\
\hline $\mathrm{BC}_{4}$ & 0.553 & 0.031 & $\mathrm{AB}$ & 4.60 & 1.40 & A & 0.61 & 0.49 & A \\
\hline \multirow[t]{3}{*}{$\mathrm{AM}$} & 0.605 & 0.07 & $\mathrm{~B}$ & 6.50 & 1.40 & A & 0.51 & 0.48 & A \\
\hline & $\mathrm{K}-\mathrm{W}$ & 7.79 & & $\mathrm{~K}-\mathrm{W}$ & 3.64 & & $\mathrm{~K}-\mathrm{W}$ & 4.66 & \\
\hline & $P$ value & 0.025 & & $P$ value & 0.332 & & $P$ value & 0.207 & \\
\hline
\end{tabular}

Identical letters denote genetic types that did not differ significantly $(P \geq 0.05)$ based upon Dunn's tests. For this table and all subsequent tables, genetic types are listed in approximate ascending order of $C$. dentata parentage and key to genetic types can be found in Supplement 1

${ }^{\text {a }} \mathrm{N}=1$ bulk sample per genetic line

${ }^{\mathrm{b}} \mathrm{N}=2$ replicates from a single bulk sample per genetic line

Table 2 Embryo chemical data and results of $\mathrm{K}-\mathrm{W}$ tests for samples collected in 2015 and $2017(\mathrm{~N}=10$ $\mathrm{CH}, 12 \mathrm{BC}_{3}, 4 \mathrm{BC}_{4}$, and $12 \mathrm{AM}$ lines)

\begin{tabular}{|c|c|c|c|c|c|c|c|c|c|c|}
\hline \multicolumn{5}{|c|}{ Lipids (\% dry mass) } & \multicolumn{3}{|c|}{ Proteins ( $\%$ dry mass) } & \multicolumn{3}{|c|}{ Phenolics (mg/g dry mass) } \\
\hline \multirow{2}{*}{$\frac{\text { Type }}{\mathrm{CH}}$} & \multicolumn{2}{|l|}{ Mean } & \multicolumn{2}{|l|}{ SD } & \multirow{2}{*}{$\begin{array}{l}\text { Mean } \\
2.7 \%\end{array}$} & \multicolumn{2}{|l|}{$\mathrm{SD}$} & \multirow{2}{*}{$\frac{\text { Mean }}{6.6}$} & \multicolumn{2}{|c|}{$\mathrm{SD}$} \\
\hline & $2.6 \%$ & & $0.7 \%$ & A & & $0.8 \%$ & $\mathrm{~B}$ & & 1.8 & A \\
\hline $\mathrm{BC}_{3}$ & $13.6 \%$ & & $3.6 \%$ & B & $3.4 \%$ & $1.0 \%$ & $\mathrm{AB}$ & 7.6 & 2.3 & A \\
\hline $\mathrm{BC}_{4}$ & $13.6 \%$ & & $1.2 \%$ & B & $3.1 \%$ & $0.7 \%$ & $\mathrm{AB}$ & 9.2 & 2.1 & A \\
\hline \multirow[t]{3}{*}{$\mathrm{AM}$} & $15.1 \%$ & & $2.8 \%$ & B & $4.0 \%$ & $0.6 \%$ & A & 6.8 & 0.9 & A \\
\hline & $\mathrm{K}-\mathrm{W}$ & & 21.3 & & $\mathrm{~K}-\mathrm{W}$ & 11.1 & & $\mathrm{~K}-\mathrm{W}$ & 6.8 & \\
\hline & $P$ value & & $<0.001$ & & $P$ value & $<0.00$ & & $P$ value & 0.0 & \\
\hline \multicolumn{4}{|c|}{ TNC (\% dry mass) } & & \multicolumn{3}{|c|}{ Starch (\% dry mass) } & \multicolumn{3}{|c|}{ Total sugars ( $\%$ dry mass) } \\
\hline Type & Mean & $\mathrm{SD}$ & & & Mean & SD & & Mean & SD & \\
\hline $\mathrm{CH}$ & $87.0 \%$ & $9.8 \%$ & A & & $78.3 \%$ & $9.9 \%$ & A & $8.8 \%$ & $1.9 \%$ & A \\
\hline $\mathrm{BC}_{3}$ & $76.6 \%$ & $7.1 \%$ & $\mathrm{~B}$ & & $69.1 \%$ & $5.4 \%$ & A & $7.6 \%$ & $1.2 \%$ & A \\
\hline $\mathrm{BC}_{4}$ & $76.7 \%$ & $8.2 \%$ & $\mathrm{AB}$ & & $69.4 \%$ & $7.0 \%$ & A & $7.3 \%$ & $0.7 \%$ & A \\
\hline \multirow[t]{3}{*}{$\mathrm{AM}$} & $78.2 \%$ & $8.0 \%$ & $\mathrm{AB}$ & & $71.3 \%$ & $7.3 \%$ & A & $6.9 \%$ & $1.7 \%$ & A \\
\hline & $\mathrm{K}-\mathrm{W}$ & 11.1 & & & $\mathrm{~K}-\mathrm{W}$ & 4.02 & & $\mathrm{~K}-\mathrm{W}$ & 5.41 & \\
\hline & $P$ value & 0.008 & & & $P$ value & 0.266 & & $P$ value & 0.142 & \\
\hline
\end{tabular}

Identical letters denote groups that did not differ significantly $(P>0.05)$ based upon Dunn's tests

types, in only one case (HWSW) did the $\mathrm{AM}$ and $\mathrm{BC}_{3}$ type not differ significantly from the $\mathrm{CH}$ type.

The first two vectors of the PCA analysis for nut morphological variables explained $\sim 64 \%$ of the overall variation ( $48 \%$ and $\sim 16 \%$ for PC1 and PC2, respectively). 


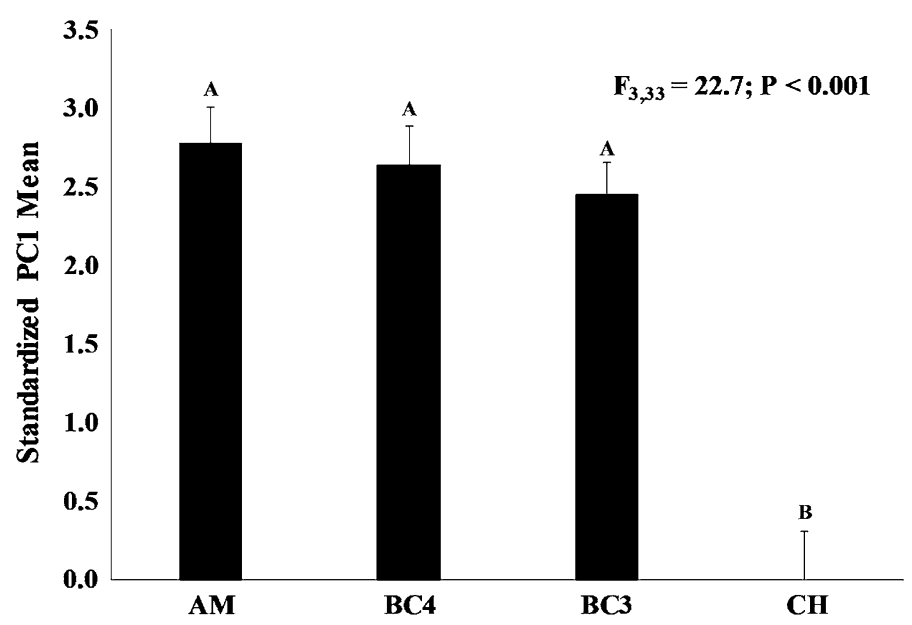

Fig. 2 Mean ( \pm S.E.) PC1 scores (standardized by subtracting the minimum) for genetic types based upon PCA using embryo chemical variables for 2015 and 2017 samples combined $\left(\mathrm{N}=12 \mathrm{AM}, 12 \mathrm{BC}_{3}, 4 \mathrm{BC}_{4}\right.$, and $10 \mathrm{CH}$ lines). Identical letters denote genetic types that did not differ significantly $(P>0.05)$ based upon Tukey's tests following one-way ANOVA

Scores on PC1 but not PC2 varied among genetic types based upon ANOVA, so we show results only for PC1. PC1 scores were positively related with SLL, HRS, SL, ALHW, and HWSW (AM chestnut-like traits), and negatively related with variables related to overall nut size ( $\mathrm{CH}$ chestnut-like traits). On $\mathrm{PC} 1$, Tukey's tests distinguished $\mathrm{CH}$ from $\mathrm{BC}_{3}, \mathrm{BC}_{4}$, and AM types; Fig. 3). This suggests that overall nut morphology of backcross and AM lines was indistinguishable.

\section{Seedling morphology and growth 2015 samples}

For seedlings grown in 2016, significant ANOVA results were found only for only one leaf variable (LN) and for four stem variables (BD, BA, HT, and VOL; Table 4). For LN, BD, $\mathrm{BA}$, and VOL, Tukey's tests showed $\mathrm{CH}$ types to differ significantly from backcross and AM types. For two variables, relationships were complex, with Tukey's tests showing two groups for $\mathrm{LA}\left(\mathrm{CH}=\mathrm{BC}_{3}=\mathrm{BC}_{4} ; \mathrm{CH}=\mathrm{BC}_{4}=\mathrm{AM}\right)$ and three groups for $\mathrm{HT}\left(\mathrm{CH} ; \mathrm{BC}_{3}=\mathrm{BC}_{4}\right.$; $\left.\mathrm{BC}_{4}=\mathrm{AM}\right)$. So, of the variables studied, only $\mathrm{HT}$ showed a suggestion of intermediate values for $\mathrm{BC}_{3}$ types. That said, mean $\mathrm{HT}$ for $\mathrm{CH}$ types was about $50 \%$ taller than $\mathrm{BC}_{3}$ types (32.3 vs. $19.7 \mathrm{~cm}$ ), whereas $\mathrm{BC}_{3}, \mathrm{BC}_{4}$ and $\mathrm{AM}$ types differed proportionately less $(19.3$, 17.4 , and $14.9 \mathrm{~cm}$, respectively).

PCA using seedling morphological and growth variables from 2016 samples showed considerable variation, with only $\sim 65 \%$ of the overall variation explained by the first three PC axes $(\sim 32 \%, \sim 17 \%$, and $\sim 15 \%$ for PC1, PC2, and PC3, respectively). Nonetheless, ANOVA showed significant differences among genetic types for both PC1 and PC2. In both cases, Tukey's tests showed $\mathrm{CH}$ types to differ significantly from backcross and AM types (Fig. 4). Scores on the PC1 axis were positively related to stem size variables and negatively with relative growth variables and HTBA ratio. Scores on the PC2 axis were positively related with LL and LLLW ratio, and negatively with HT, LN, HTBA ratio, and relative growth parameters other than RGRLN. 
Table 3 Nut morphological data and ANOVA results for samples collected fall $2017\left(\mathrm{~N}=7 \mathrm{CH}, 15 \mathrm{BC}_{3}, 3\right.$ $\mathrm{BC}_{4}$, and $11 \mathrm{AM}$ lines)

\begin{tabular}{|c|c|c|c|c|c|c|c|c|c|}
\hline Cross type & $\mathrm{L}$ & $\mathrm{W}$ & $\mathrm{D}$ & SVOL & SA & HW & $\mathrm{HH}$ & HA & HASA \\
\hline \multirow[t]{3}{*}{$\mathrm{CH}$} & 27.28 & 30.30 & 23.12 & 10,554 & 2007 & 23.00 & 16.73 & 299.3 & 0.151 \\
\hline & 3.45 & 4.62 & 4.61 & 3336 & 436 & 4.88 & 3.746 & 80.92 & 0.036 \\
\hline & A & A & A & A & A & A & A & A & A \\
\hline \multirow[t]{3}{*}{$\mathrm{BC}_{3}$} & 20.99 & 21.20 & 13.66 & 3606 & 979 & 17.50 & 11.14 & 154.5 & 0.156 \\
\hline & 2.75 & 2.55 & 2.16 & 1288 & 234 & 1.97 & 3.58 & 50.0 & 0.024 \\
\hline & B & B & B & B & B & B & B & B & A \\
\hline \multirow[t]{3}{*}{$\mathrm{BC}_{4}$} & 23.31 & 23.90 & 14.54 & 4887 & 1200 & 21.41 & 12.24 & 207.5 & 0.178 \\
\hline & 6.51 & 0.77 & 0.16 & 1936 & 281 & 1.3 & 0.257 & 17.3 & 0.041 \\
\hline & $\mathrm{AB}$ & B & B & B & $\mathrm{B}$ & $\mathrm{AB}$ & $\mathrm{AB}$ & B & A \\
\hline \multirow[t]{3}{*}{$\mathrm{AM}$} & 20.28 & 20.99 & 14.20 & 3515 & 961 & 18.24 & 10.82 & 157.6 & 0.163 \\
\hline & 3.19 & 2.63 & 3.15 & 1333 & 236 & 2.99 & 2.64 & 49.8 & 0.039 \\
\hline & B & B & B & B & B & B & B & B & A \\
\hline $\mathrm{F}_{3,32}$ & 9.8 & 22.2 & 33.0 & 50.7 & 39.2 & 8.66 & 7.42 & 18.1 & 1.0 \\
\hline$P$ value & $<0.001$ & $<0.001$ & $<0.001$ & $<0.001$ & $<0.001$ & $<0.001$ & $<0.001$ & $<0.001$ & 0.406 \\
\hline Cross type & \multicolumn{2}{|c|}{ HWSW } & $\mathrm{AL}$ & \multicolumn{2}{|c|}{ ALHW } & HRS & \multicolumn{2}{|l|}{ SL } & SLL \\
\hline \multirow[t]{3}{*}{$\mathrm{CH}$} & \multicolumn{2}{|c|}{0.760} & 4.19 & \multicolumn{2}{|l|}{0.190} & 8.64 & \multicolumn{2}{|l|}{6.07} & 0.224 \\
\hline & \multicolumn{2}{|c|}{0.104} & 1.46 & 0.075 & & 8.4 & \multicolumn{2}{|l|}{5.22} & 0.192 \\
\hline & \multicolumn{2}{|l|}{ A } & $\mathrm{AB}$ & A & & A & \multicolumn{2}{|l|}{ A } & A \\
\hline \multirow[t]{3}{*}{$\mathrm{BC}_{3}$} & \multicolumn{2}{|c|}{0.832} & 4.70 & 0.272 & & 56.9 & \multicolumn{2}{|l|}{15.3} & 0.724 \\
\hline & \multicolumn{2}{|c|}{0.076} & 1.01 & 0.061 & & 15.39 & \multicolumn{2}{|l|}{4.15} & 0.131 \\
\hline & \multicolumn{2}{|c|}{$\mathrm{AB}$} & B & A & & B & \multicolumn{2}{|l|}{ B } & B \\
\hline \multirow[t]{3}{*}{$\mathrm{BC}_{4}$} & \multicolumn{2}{|c|}{0.894} & 7.55 & 0.355 & & 49.27 & \multicolumn{2}{|l|}{14.27} & 0.641 \\
\hline & \multicolumn{2}{|c|}{0.044} & 1.51 & 0.081 & & 44 & \multicolumn{2}{|l|}{3.8} & 0.248 \\
\hline & \multicolumn{2}{|l|}{ B } & A & A & & B & $\mathrm{B}$ & & B \\
\hline $\mathrm{AM}$ & 0.8 & & 5.36 & 0.304 & & 43.29 & 13.37 & & 0.658 \\
\hline & 0.0 & & 1.95 & 0.128 & & 20.13 & 4.24 & & 0.188 \\
\hline & B & & $\mathrm{AB}$ & A & & B & B & & B \\
\hline $\mathrm{F}_{3,32}$ & 5.0 & & 2.73 & 1.83 & & 11.74 & 10.0 & & 21.94 \\
\hline$P$ value & 0.0 & & 0.060 & 0.162 & & $<0.001$ & $<0.001$ & & $<0.001$ \\
\hline
\end{tabular}

Results are means and standard deviations. ANOVA was conducted using mean values for each genetic line. Identical letters within a column denote genetic types that did not differ significantly $(P \geq 0.05)$ based upon Tukey's tests. See Supplement 2 for variable definitions

For lines for which both seed and seedling traits were measured, we regressed seedling stem volume (VOL) on dry seed mass (Fig. 5). A power function showed a very strong relationship $\left(\mathrm{R}^{2}>90\right)$ between these variables, and the 10 backcross/AM lines nested in a cluster apart from the four $\mathrm{CH}$ lines.

\section{Seedling morphology and growth 2016 samples}

For seedlings grown in 2017, ANOVA did not detect any significant differences among $\mathrm{BC}_{3}, \mathrm{BC}_{4}$, and $\mathrm{AM}$ lines for any leaf or stem trait $\left(\mathrm{F}_{2,9}\right.$ ranged from 0.1 for $\mathrm{LW}$ to 3.0 for 


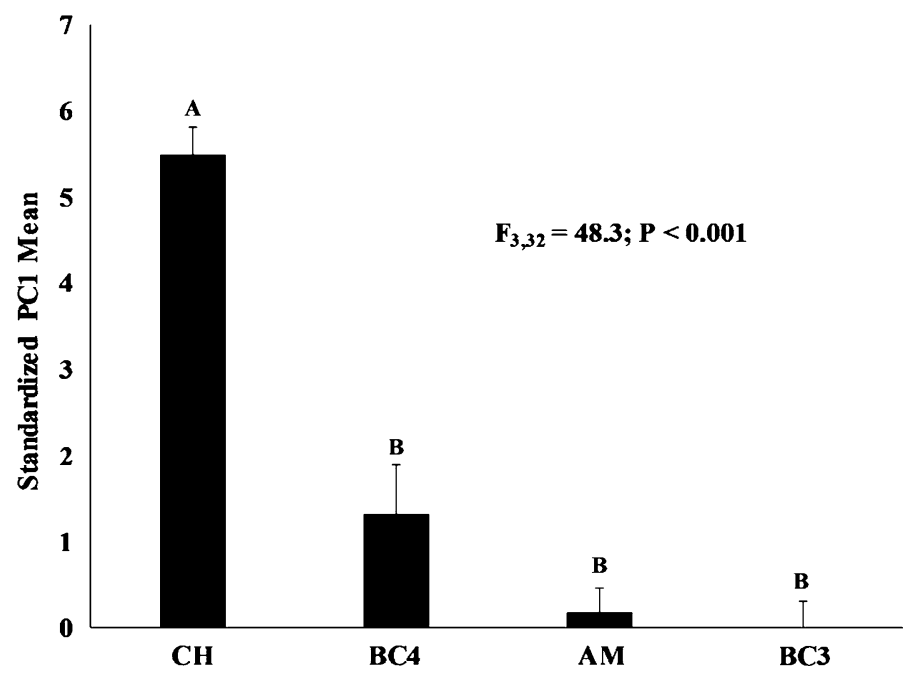

Fig. 3 Mean ( \pm S.E.) Mean PC1 scores (standardized by subtracting the minimum) for genetic types based upon PCA using nut morphological variables for 2017 samples $\left(\mathrm{N}=7 \mathrm{CH}, 3 \mathrm{BC}_{4}, 11 \mathrm{AM}\right.$, and $15 \mathrm{BC}_{3}$ lines). Identical letters denote genetic types that did not differ significantly $(P>0.05)$ based upon Tukey's tests following one-way ANOVA

LLLW; $P>0.05$ for all variables). As for seedlings grown in 2016, there was considerable overall variation; in this case, the first three PC axis explained only $68 \%$ of the overall variation $(\sim 34 \%, \sim 19 \%$, and $\sim 15 \%$ for PC1, PC2, and PC3, respectively). As with the original variables, ANOVA could not detect significant differences among genetic types for either PC1 or PC2 scores $\left(\mathrm{F}_{2,9}<2.6, P>0.05\right.$ for both PC variables).

Only six genetic lines had both seed and seedling traits measured in 2016/2017 (too few to determine a valid statistical relationship). Nevertheless, a graph of the relationship between seed volume (SVOL) and seedling stem volume (VOL) was at least suggestive of an influence of seed size on seedling size (Fig. 5).

\section{Discussion}

Our results support the prediction that seeds and seedlings of blight-resistant $\mathrm{BC}_{3}$ and $\mathrm{BC}_{4}$ trees show a combination of phenotypic traits that commonly differ from $\mathrm{CH}$ chestnut, but cannot be routinely distinguished from those of $\mathrm{AM}$ chestnut. Selected $\mathrm{BC}_{3}$ parent trees at Berry College (Supplement 1) had been previously shown to exhibit adult morphological characteristics indistinguishable from those of $\mathrm{AM}$ chestnut (Cipollini et al. 2017). It should be noted that most of the $\mathrm{BC}_{3} \mathrm{~F}_{2}$ and $\mathrm{BC}_{4} \mathrm{~F}_{2}$ seeds used in this study are not expected to carry the full complement of blight-resistance genes of the parent trees; the theoretical framework suggests that only a fraction of the offspring might carry significant blight resistance (Burnham et al. 1986).

The main difference in nutritional quality of AM and backcross chestnuts was lipid content, which was nearly an order of magnitude higher than that of $\mathrm{CH}$ chestnuts. This difference might explain common perceptions of a relatively "sweeter" flavor for AM versus CH chestnuts (Senter et al. 1994; Anagnostakis and Devin 2004). Lipid content is an important predictor of attractiveness of nut-bearing trees to potential seed dispersers 
Table 4 Seedling morphological and growth data and ANOVA results for seed samples collected in fall 2015 and grown in spring $2016\left(\mathrm{~N}=4 \mathrm{CH}, 10 \mathrm{BC}_{3}, 3 \mathrm{BC}_{4}\right.$, and $\left.3 \mathrm{AM}\right)$

\begin{tabular}{|c|c|c|c|c|c|c|c|c|c|}
\hline & \multicolumn{7}{|c|}{ Leaf variables } & \multicolumn{2}{|c|}{ Stem variables } \\
\hline & $\mathrm{LN}$ & LL & LW & LA & LLLW & RGRLN & RGRLA & $\mathrm{BD}$ & $\mathrm{BA}$ \\
\hline \multirow[t]{3}{*}{$\mathrm{CH}$} & 8.9 & 14.0 & 5.8 & 81.9 & 2.39 & -0.003 & 0.012 & 3.8 & 11.3 \\
\hline & 1.5 & 4.1 & 1.4 & 35.2 & 0.36 & 0.013 & 0.037 & 0.5 & 2.7 \\
\hline & $\mathrm{A}$ & A & A & $\mathrm{AB}$ & A & A & A & A & A \\
\hline \multirow[t]{3}{*}{$\mathrm{BC}_{3}$} & 6.1 & 15.4 & 5.9 & 91.9 & 2.64 & -0.004 & 0.003 & 3.0 & 7.5 \\
\hline & 1.6 & 2.6 & 1.1 & 27.7 & 0.34 & 0.014 & 0.014 & 0.5 & 2.6 \\
\hline & B & A & A & A & A & A & A & B & B \\
\hline \multirow[t]{3}{*}{$\mathrm{BC}_{4}$} & 6.4 & 14.4 & 5.5 & 79.0 & 2.67 & -0.003 & -0.002 & 3.0 & 7.0 \\
\hline & 1.7 & 1.8 & 0.9 & 18.3 & 0.38 & 0.023 & 0.016 & 0.3 & 1.3 \\
\hline & $\mathrm{B}$ & A & A & $\mathrm{AB}$ & $\mathrm{A}$ & A & A & B & $\mathrm{B}$ \\
\hline \multirow[t]{3}{*}{$\mathrm{AM}$} & 6.4 & 12.9 & 4.8 & 62.2 & 2.70 & -0.002 & 0.001 & 3.0 & 7.2 \\
\hline & 1.2 & 1.6 & 0.8 & 14.6 & 0.33 & 0.005 & 0.012 & 0.5 & 2.4 \\
\hline & $\mathrm{B}$ & A & A & $\mathrm{B}$ & A & A & A & B & B \\
\hline $\mathrm{F}_{3,16}$ & 8.51 & 3.50 & 1.71 & 3.95 & 1.86 & 0.24 & 2.76 & 8.25 & 9.33 \\
\hline \multirow[t]{3}{*}{$P$ value } & 0.001 & 0.041 & 0.204 & 0.028 & 0.177 & 0.865 & 0.076 & 0.002 & $<0.001$ \\
\hline & \multicolumn{9}{|c|}{ Stem variables } \\
\hline & \multicolumn{2}{|c|}{$\overline{\mathrm{HT}}$} & VOL & \multicolumn{2}{|r|}{ HTBA } & RGRBA & \multicolumn{2}{|l|}{ RGRHT } & $\overline{\text { RGRVOL }}$ \\
\hline \multirow[t]{3}{*}{$\mathrm{CH}$} & \multicolumn{2}{|c|}{32.2} & 12.2 & \multicolumn{2}{|r|}{3.0} & 0.001 & \multicolumn{2}{|l|}{0.006} & 0.006 \\
\hline & \multicolumn{2}{|c|}{5.4} & 4.1 & \multicolumn{2}{|r|}{0.8} & 0.037 & \multicolumn{2}{|l|}{0.010} & 0.041 \\
\hline & \multicolumn{2}{|c|}{ A } & A & \multicolumn{2}{|r|}{ A } & A & \multicolumn{2}{|l|}{ A } & A \\
\hline \multirow[t]{3}{*}{$\mathrm{BC}_{3}$} & \multicolumn{2}{|c|}{19.7} & 5.0 & \multicolumn{2}{|r|}{2.8} & -0.012 & \multicolumn{2}{|l|}{0.008} & -0.004 \\
\hline & \multicolumn{2}{|c|}{4.6} & 2.3 & \multicolumn{2}{|r|}{0.9} & 0.045 & \multicolumn{2}{|l|}{0.063} & 0.079 \\
\hline & B & & $\mathrm{B}$ & & A & A & A & & A \\
\hline $\mathrm{BC}_{4}$ & & & 4.1 & & 2.5 & -0.007 & 0.002 & & -0.004 \\
\hline & 2 & & 1.0 & & 0.6 & 0.028 & 0.008 & & 0.029 \\
\hline & B & & B & & A & A & A & & A \\
\hline $\mathrm{AM}$ & & & 3.6 & & 2.3 & -0.017 & 0.002 & & -0.015 \\
\hline & 2 & & 1.5 & & 1.1 & 0.040 & 0.005 & & 0.041 \\
\hline & $\mathrm{C}$ & & B & & A & A & A & & A \\
\hline $\mathrm{F}_{3,16}$ & & & 54.02 & & 0.25 & 0.12 & 0.10 & & 1.33 \\
\hline$P$ value & & 001 & $<0.001$ & & 0.863 & 0.950 & 0.959 & & 0.299 \\
\hline
\end{tabular}

Results are means and standard deviations. ANOVAs were calculated using means for each genetic line. Identical letters within a column denote genetic types that did not differ significantly $(P \geq 0.05)$ based upon Tukey's tests. See Supplement 2 for variable definitions

(e.g., squirrels; Smith and Follmer 1972; Burke 2013). If backcross chestnuts are to fill the niche formerly occupied by AM chestnut, dispersers and seed predators should perceive and respond to them equally. Our results suggest that this should be the case, if the nutrients we assayed are proximate factors in seed selection. The proximate assays we used may be influenced to some degree by qualitative differences in constituent profiles. 

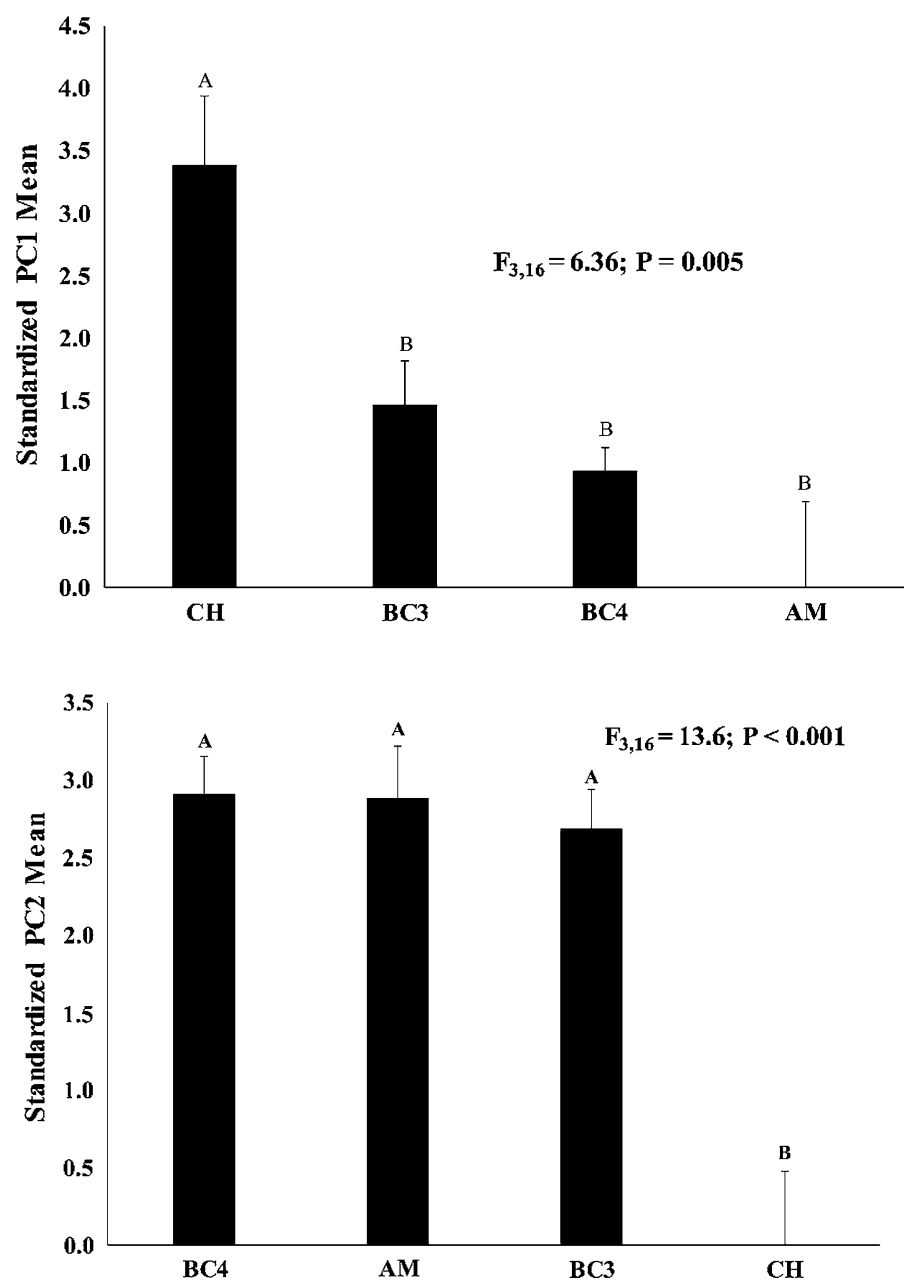

Fig. 4 Mean ( \pm S.E.) PC1 (upper figure) and PC2 (lower figure) scores (standardized by subtracting the minimum) for genetic types based upon PCA for seedling morphological and growth variables for 2015 samples grown in $2016\left(\mathrm{~N}=4 \mathrm{CH}, 9 \mathrm{BC}_{3}, 3 \mathrm{BC}_{4}\right.$, and $3 \mathrm{AM}$ lines). Identical letters denote genetic types that did not differ significantly $(P>0.05)$ based upon Tukey's tests following one-way ANOVA

That said, when applied in comparisons of closely related genetic types, they should reflect relative variation in these chemical classes.

Seed and early seedling morphology and physiology is thought to be influenced by the genetic makeup and environment of the parent plant more so than the genotype of the embryo (González-Rodrígueza et al. 2011; Singh et al. 2017). This is partly through maternal effects that affect provisioning of resources to embryos. In our case, difference in size of seedlings was strongly related to differences in seed size. That said, Anagnostakis (2009) and Zang et al. (2016) suggested that pollen source may influence nutritional quality and morphology of Castanea nuts. As such, pollen source could potentially affect seed quality and early seedling morphology. In our study, pollinators were of the same genetic type as the maternal tree (e.g., AM X opAM=AM, etc.). The expectation for restoration is that backcross trees will be pollinated by other backcross trees or by wild-type 

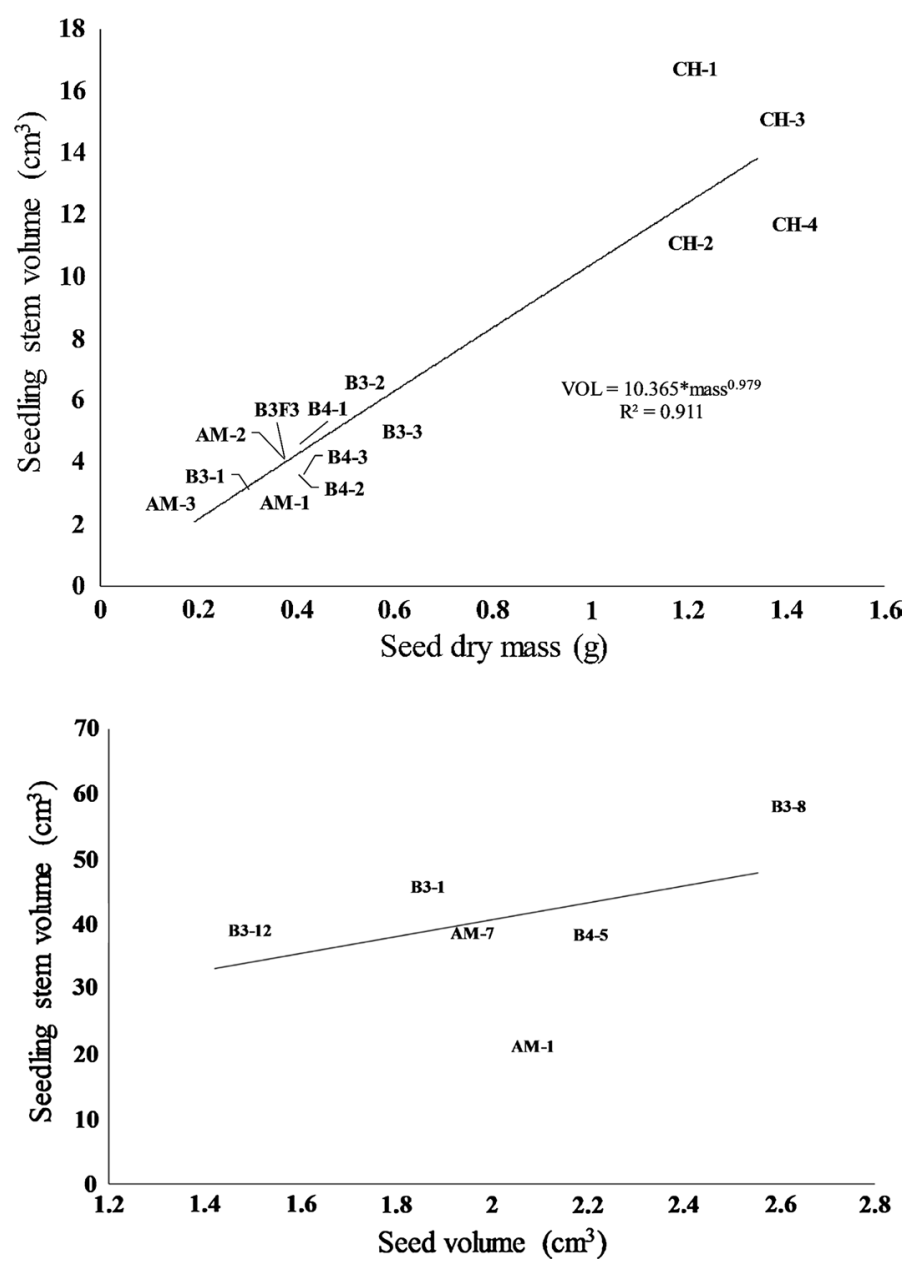

Fig. 5 Relationship between mean seed mass and mean seedling stem volume for genetic lines collected in 2015 and grown in 2016 (upper figure) and relationship between mean seed volume and mean seedling stem volume for genetic lines sampled in 2016 and grown in 2017 (lower figure). For key to genetic lines, see Supplement 1

AM chestnuts. As such, concern over variation among pollen sources strongly influencing nut quality should be minimal.

Because the seedlings used in our 2016 study had to be immediately transported to a distant field site, our estimates of relative growth parameters were compromised by a relatively short period of elapsed time (1 week) between the first and second morphological measurements. In fact, some lines apparently shrank in certain size parameters (e.g., BD) between measurement periods, most likely a product of the hardening up of woody tissue and/or differences in seedling moisture content between measurements. The 2017 experiment spanned a longer time frame (36 days). Neither experiment demonstrated strong or consistent differences among $\mathrm{AM}, \mathrm{BC}_{4}$, and $\mathrm{BC}_{3}$ lines in morphology and early growth. For example, while $\mathrm{BC}_{3}$ seedlings seemed to exhibit higher LA than AMs in 2016, this difference was not apparent in 2017 when larger number of replicates were used (10 in 2016, 
20 in 2017). Some silvicultural studies suggest culling small seedlings prior to out-planting backcross hybrids (e.g., Clark et al. 2014; Clark et al. 2016). While useful for ensuring high early survival rates in the field, culling to retain only the largest seedlings may carry risks of inadvertently selecting for $\mathrm{CH}$ chestnut traits linked to large seedling size. In particular, due to the relationship of seed size to seedling size, this practice could select for greater seed size (a CH-like trait). Culling should therefore probably only be done when seedlings are significantly outside the range of the natural variation of AM chestnuts.

Our results, at the minimum, support the hypothesis that backcross trees selected for blight resistance produce nuts and seedlings that are not reliably distinguishable from those of AM chestnut. These results thus support previous studies showing that the TACF backcross breeding program is accomplishing the goal of bringing blight resistance into trees of an otherwise AM chestnut morphology (Diskin et al. 2006; Cipollini et al. 2017). That said, recent evidence suggests that blight resistance may be quantitative and obtaining fixation for full blight resistance in $\mathrm{BC}_{3}$ and $\mathrm{BC}_{4}$ generations will not likely be possible (Westbrook et al. 2019a). It is uncertain, without further field study, whether the current level of blight resistance in these generations is sufficient for restoration (Clark et al. 2019). To obtain acceptable blight resistance through this program, it may be necessary to employ earlier generations (e.g., $\mathrm{BC}_{2}$ ) or to utilize particular crosses to achieve acceptable resistance (e.g., selected $\mathrm{F} 1 \times \mathrm{BC}_{3}$ crosses). If earlier generations are to be used for restoration, studies of nut and seedling traits analogous as those employed in this study ought to confirm that differences from wild-type AM chestnuts are not significant, or if so, are not so pronounced as to be ecologically important. Regardless of the approach to obtaining blight resistance in restoration of AM chestnut, studies of range-wide genetic and ecological variation (and relations among these variables) are paramount. This study was limited to a relatively small number of samples from states with TACF backcross programs. Analysis of larger populations at the landscape level will help inform breeding efforts directed towards strategically diversifying the population of trees incorporated into the TACF breeding program and its companion transgenic program (Westbrook et al. 2019c).

Acknowledgements Field and lab assistance from Berry College interns Matthew Summerlin, Reid Poppel, William Watkins, Erin Coughlin, Samuel Watkins, Theron Kantelis, Gracelyn Jones, Shadae Williams, Patrick Felch, Royce Dingley, and Zach Lemcke, and from Berry College Principles of Microbiology and Botany students; seed samples provided by Paul Sisco, J. Hill Craddock, Thomas Saielli, Frederick Hebard, Laura Georgi, Sarah Fitzsimmons, Ben Jarrett, Steve Hoy, Jack Lamonica, Thomas Klak, Brian Roth; funding provided by Berry College, Mary Belle Price, National Forest Foundation, Georgia Appalachian Regional Commission, and The Georgia Chapter of TACF.

Open Access This article is distributed under the terms of the Creative Commons Attribution 4.0 International License (http://creativecommons.org/licenses/by/4.0/), which permits unrestricted use, distribution, and reproduction in any medium, provided you give appropriate credit to the original author(s) and the source, provide a link to the Creative Commons license, and indicate if changes were made.

\section{References}

Anagnostakis SL (1987) American chestnut blight: the classical problem of an introduced pathogen. Mycologia 79:23-37

Anagnostakis SL (2009) Fats, protein, carbohydrates and fatty acids in chestnut fruits. Acta Hortic 815:57-60

Anagnostakis SL, Devin P (2004) Nutrients in chestnuts. J Am Chestnut Found 18(1):38-41

Analytical Software, Inc (2013) Statistix 10. Analytical Software, Tallahassee, Florida. https://www.stati stix.com/. Accessed 26 July 2019 
AOAC International (2012) Official methods of analysis of AOAC international, 19th ed. AOAC International, Gaithersburg, MD, USA, Official Method 948.22

Budini R, Tonelli D, Girotti S (1980) Analysis of total phenols using the Prussian Blue Method. J Agric Food Chem 28:1236-1238

Burke KL (2013) Chestnuts and wildlife. J Am Chestnut Found 27(2):9-12

Burnham CR, Rutter PA, French DW (1986) Breeding blight-resistant chestnuts. Plant Breed Rev 4:347-397

Chenlo F, Moreira R, Chaguri L, Torres MD (2010) Effects of storage conditions on sugars and moisture content of whole chestnut fruits. J Food Process Preserv 34(4):609-620. https://doi.org/10.111 1/j.1745-4549.2008.00361.x

Cipollini ML, Dingley NR, Felch P, Maddox C (2017) Evaluation of phenotypic traits and blight-resistance in an American chestnut backcross orchard in Georgia. Glob Ecol Conserv 10:1-8. https://doi. org/10.1016/j.gecco.2017.01.004

Clark SL, Schlarbaum SE, Saxton AM, Hebard FV (2012) Nursery performance of American and Chinese chestnuts and backcross generations in commercial tree nurseries. Forestry (Lond) 85(5):589-600. https://doi.org/10.1093/forestry/cps068

Clark SL, Schlarbaum SE, Pinchot CC, Anagnostakis SL, Saunders MR, Thomas-Van Gundy M, Schaberg P, McKenna J, Bard JF, Berrang PC, Casey DM, Casey CE, Crane B, Jackson BD, Kochenderfer JD, Lewis MacFarlane RF, Makowske R, Miller MD, Rodrigue JA, Stelick J, Thornton CD, Williamson TS (2014) Reintroduction of American chestnut in the National Forest System. J For 112(5):502-512. https://doi.org/10.5849/jof.13-106

Clark SL, Schlarbaum SE, Saxton AM, Hebard FV (2016) Establishment of American chestnuts (Castanea dentata) bred for blight (Cryphonectria parasitica) resistance: influence of breeding and nursery grading. New For 47:243-270. https://doi.org/10.1007/s11056-015-9512-6

Clark SL, Schlarbaum SE, Saxton AM, Baird R (2019) Eight-year blight (Cryphonectria parasitica) resistance of backcross generation American chestnuts (Castanea dentata) planted in the southeastern United States. Forest Ecol Manag 433:153-161. https://doi.org/10.1016/j.foreco.2018.10.060

Dalgleish HJ, Nelson CD, Scrivani JA, Jacobs DF (2015) Consequences of shifts in abundance and distribution of American chestnut for restoration of a foundation forest tree. Forests. https://doi.org/10.3390/ f7010004

De Vasconcelos MCBM, Nunes F, Viguera CG, Bennett RN, Rosa EAS, Ferreira-Cardoso JV (2010) Industrial processing effects on chestnut fruits (Castanea sativa Mill.) 3. Minerals, free sugars, carotenoids and antioxidant vitamins. Int J Food Sci Technol 45(3):1365-2621. https://doi.org/10.111 1/j.1365-2621.2009.02155.x

Diskin M, Steiner KC, Hebard FV (2006) Recovery of American chestnut characteristics following hybridization and backcross breeding to restore blight-ravaged Castanea dentata. For Ecol Manag 223:439-447

Fitzsimmons S, Gurney K, White W, McCune K (2012) The chapter breeding program of the American Chestnut Foundation. In: Sniezko RA, Yanchuk AD, Kliejunas JT, Palmieri KM, Alexander JM, Frankel, SJ (Tech Coords) Proceedings of the 4th international workshop on genetics of host-parasite interactions in forestry. Gen Tech Rep PSW-GTR-240. Pacific Southwest Research Station, Forest Service, U.S. Department of Agriculture, Albany, California. p 303. https://www.fs.fed.us/psw/publications/ documents/psw_gtr240/psw_gtr240_303.pdf Accessed 1 Nov 2016

Georgi L, Zhebentyayeva T, Islam-Faridi N, Vining E, Abbott A, Nelson CD, Hebard FV (2015) The search for genes for resistance to chestnut blight. J Am Chestnut Found 76:16-20

González-Rodrígueza V, Villara R, Navarro-Cerrillob RM (2011) Maternal influences on seed mass effect and initial seedling growth in four Quercus species. Acta Oecol 37(1):1-9. https://doi.org/10.1016/j. actao.2010.10.006

Griffin GJ, Hebard FV, Wendt RW, Elkins JR (1983) Survival of American chestnut trees: evaluation of blight resistance and virulence in Endothia parasitica. Phytopathology 73:1084-1092

Hebard FV (2005) The backcross breeding program of The American Chestnut Foundation. In: Steiner KC, Carlson JE (eds) Proceedings of a conference on restoration of American chestnut to forest lands. Natural Resources Report NPS/NCR/CUE/NRR—2006/001, Asheville, North Carolina, pp 1-17. https:// ecosystems.psu.edu/research/chestnut/information/conference-2004/conference/conference-proceeding s. Accessed 11 Jan 2016

Hebard FV (2012) The American Chestnut Foundation breeding program. In: Sniezko RA, Yanchuk AD, Kliejunas JT, Palmieri KM, Alexander JM, Frankel SJ (Tech coords) Proceedings of the 4th international workshop on genetics of host-parasite interactions in forestry. Gen Tech Rep PSW-GTR-240. Pacific Southwest Research Station, Forest Service, U.S. Department of Agriculture, Albany, California. pp 221-234 https://www.fs.fed.us/psw/publications/documents/psw_gtr240/psw_gtr240_221.pdf. Accessed 1 Nov 2016 
Hernández Suárez M, Rodríguez Galdón B, Ríos Mesa D, Díaz Romero C, Rodríguez Rodríguez E (2012) Sugars, organic acids and total phenols in varieties of chestnut fruits from Tenerife (Spain). Food Nutr Sci 3:705-715. https://doi.org/10.4236/fns.2012.36096

Jacobs DF, Dalgleish HJ, Nelson CD (2013) A conceptual framework for restoration of threatened plants: the effective model of American chestnut (Castanea dentata) reintroduction. New Phytol 197:378-393

Jeffers SN, Meadows IM, James JB, Sisco PH (2012) Resistance to Phytophthora cinnamomi among seedlings from backcross families of hybrid American chestnut. In: Sniezko RA, Yanchuk AD, Kliejunas JT, Palmieri KM, Alexander JM, Frankel SJ (Tech coords) Proceedings of the 4th international workshop on genetics of host-parasite interactions in forestry. Gen Tech Rep PSW-GTR-240. Pacific Southwest Research Station, Forest Service, U.S. Department of Agriculture, Albany, California. pp 194195. https://www.fs.fed.us/psw/publications/documents/psw_gtr240/psw_gtr240_194.pdf Accessed 11 Jan 2016

Jones CG, Hare DJ, Compton SJ (1989) Measuring plant protein with the Bradford Assay I Evaluation and standard method. J Chem Ecol 15(3):979-992

Knapp BO, Wang GG, Clark SL, Pile LS, Schlarbaum SE (2014) Leaf physiology and morphology of Castanea dentata (Marsh) Borkh., Castanea mollissima Blume, and three backcross breeding generations planted in the southern Appalachians, USA. New For 45(2):283-293. https://doi.org/10.1007/s1105 6-014-9408-X

Li BW, Schuhmann PJ, Wolf WR (1985) Chromatographic determinations of sugars and starch in a diet composite reference material. J Agric Food Chem 33:531-536

McDonald JH (2014) Handbook of biological statistics. Sparky House Publishing, Baltimore

Michon G (2018) Final answers. Spheroids and scalene ellipsoids. https://www.numericana.com/answer/ ellipsoid.htm\#ellipsoid. Accessed 6 Dec 2018

Milgroom MG, Cortesi P (2004) Biological control of chestnut blight with hypovirulence: a critical analysis. Annu Rev Phytopathol 42:311-338

Pinchot CC, Schlarbaum SE, Clark SL, Saxton AM, Sharp AM, Schweitzer CJ, Hebard FV (2017) Growth, survival, and competitive ability of chestnut (Castanea Mill.) seedlings planted across a gradient of light levels. New For 48:491-512. https://doi.org/10.1007/s11056-017-9577-5

Rosengarten F Jr (2004) The book of edible nuts. Dover Publications, Mineola

Senter SD, Payne JA, Miller G, Anagnostakis SL (1994) Comparison of total lipids, fatty acids, sugars and nonvolatile organic acids in nuts from four Castanea species. J Sci Food Agric 65:223-227. https://doi. org/10.1002/jsfa.2740650216

Singh J, Clavijo Michelangeli JA, Gezan SA, Lee H, Vallejos CE (2017) Maternal effects on seed and seedling phenotypes in reciprocal $\mathrm{F}_{1}$ hybrids of the common bean (Phaseolus vulgaris $\mathrm{L}$ ). Front Plant Sci 8:42. https://doi.org/10.3389/fpls.2017.00042

Skousen JG, Dallaire K, Scagline-Mellor S, Monteleone A, Wilson-Kokes L, Joyce J, Thomas C, Keene T, DeLong C, Cook T, Jacobs DF (2018) Plantation performance of chestnut hybrids and progenitors on reclaimed Appalachian surface mines. New For 49:599-611. https://doi.org/10.1007/s1105 6-018-9643-7

Smith D (1981) Removing and analyzing total nonstructural carbohydrates from plant tissues. Wis Exp Stn Bull 2107:1-11

Smith CC, Follmer D (1972) Food preferences of squirrels. Ecology 53:82-91

Spiro RG (1966) Anthrone assay for neutral sugars. In: Colowick SP, Kaplan NO (eds) Methods in enzymology, vol 8. Academic Press, New York, pp 3-26

Steiner KC, Westbrook JW, Hebard FV, Georgi LL, Powell WP, Fitzsimmons SF (2016) Rescue of American chestnut with extraspecific genes following its destruction by a naturalized pathogen. New For 48(2):317-336. https://doi.org/10.1007/s11056-016-9561-5

The American Chestnut Foundation (2018) Identification: Chinese versus American chestnut (Castanea mollissima vs. Castanea dentata). https://www.acf.org/resources/identification/chinese-american-chest nuts/. Accessed 6 Dec 2018

Wang GG, Knapp BO, Clark SL, Mudder BT (2013) The silvics of Castanea dentata (Marsh.) Borkh., American chestnut, Fagaceae (Beech Family). United States Department of Agriculture Forest Service, Southern Research Station, Gen Techn Rep SRS-173. https://www.srs.fs.fed.us/pubs/gtr/gtr_srs17 3.pdf. Accessed 6 June 2016

Westbrook J (2016) Merging genomics and biotechnology with breeding to restore the American chestnut. J Am Chestnut Found 30(3):27-31

Westbrook JW, Zhang Q, Mandal MK, Jenkins EV, Barth LE, Jenkins JW, Grimwood J, Schmutz J, Holliday JA (2019a) Genomic selection analyses reveal tradeoff between chestnut blight tolerance and genome inheritance from American chestnut $($ Castanea dentata $)$ in $(C$. dentata $\times C$. mollissima $) \times C$. dentata 
backcross populations. Evolut Appl (in review). https://www.biorxiv.org/content/10.1101/690693v1. full

Westbrook JW, James JB, Sisco PH, Frampton J, Lucas S, Jeffers SN (2019b) Resistance to Phytophthora cinnamomi in American chestnut (Castanea dentata) backcross populations that descended from two Chinese chestnut (Castanea mollissima) sources of resistance. Plant Dis. https://doi.org/10.1094/ PDIS-11-18-1976-RE

Westbrook JW, Holliday JA, Newhouse AE, Powell WA (2019c) A plan to diversify a transgenic blighttolerant American chestnut population using citizen science. Plants People Planet. https://doi. org/10.1002/ppp3.10061

Yemm EW, Willis AJ (1954) The estimation of carbohydrates in plant extracts by anthrone. Biochem J 57(3):508-514

Zhang B, Oakes AD, Newhouse AE, Baier KM, Maynard CA, Powell WA (2013) A threshold level of oxalate oxidase transgene expression reduces Cryphonectria parasitica-induced necrosis in a transgenic American chestnut (Castanea dentata) leaf bioassay. Transgenic Res 22(5):973-982

Publisher's Note Springer Nature remains neutral with regard to jurisdictional claims in published maps and institutional affiliations. 